\title{
$(12.00 .03)$
}

\section{Яковлев А.Ю. \\ ОРГАНИЗАЦИОННЫЕ И ПРАВОВЫЕ ОСНОВЫ УПРАВЛЕНИА ГОСУДАРСТВЕННЫМИ ХОЗАЙСТВЕННЫМИ ОБНЕСТВАМИ B CYGBEKTAX PФ}

\author{
Yakovlev A.Y. \\ ORGANIZATIONAL AND LEGAL BASIS \\ FOR GOVERNING STATE BUSINESS ENTITIES \\ IN RUSSIAN REGIONS
}

\begin{abstract}
Россия является крупнейшей в мире страной с достаточно разными по многим параметрам территориями. Федеративный статус государства ведет к отличиям в правовых нормах, регулирующих различные области общественных отношений, и возникновению особенностей в системах государственного управления. Вопросы, связанные с осуществлением прав акционера (участника), не являются исключением. В российских регионах имеются как особенности, так и общие черты в обозначенной области. В настоящей работе автор проведет анализ организационных и правовых аспектов управления хозяйственными обществами с участием субъектов РФ в современный исторический период.

Ключевые слова: хозяйственное общество, акционерное общество, общество с государственным участием, государственное хозяйственное общество, хозяйственное общество с государственным участием.

Russia is the largest country in the world with territories that are quite different in many respects. The federal status of the state leads to differences in legal norms in various spheres of social relations and the emergence of peculiarities in the systems of public administration. Issues related to the rights of a shareholder (participant) are not an exception. In Russian regions there are both peculiarities and common features in the designated area. In this paper the author will analyze the organizational and legal aspects of governing business entities with the participation of Russian regions in the modern historical period.

Keywords: business entity, joint-stock company, company with state participation, state business entity, business entity with state participation.
\end{abstract}

В Российской Федерации в соответствии с конституционными нормами государственную власть осуществляют федеральный центр и субъекты РФ. Государственная собственность также бывает 2-х указанных видов. Во владении субъектов федерации может находиться большой перечень самых разнообразных объектов - от транспортных средств, помещений, земельных участков до долей в хозяйственных обществах.

Наличие акций и долей ведет к необходимости построения механизма управления ими. Ввиду того, что субъекты феде- рации самостоятельно выстраиваются систему управления, порядок владения, пользования и распоряжения также каждый регион определяет сам.

В России отсутствует федеральный закон об управлении государственным имуществом в целом и долями (акциями), в частности. Субъекты федерации не ограничиваются рамками, которые, например, установлены для построения системы региональных органов, численности депутатского корпуса, сроков полномочий и др. Это предоставляет субъектам РФ больше свободы. Некоторые регионы при- 
няли законы о государственной собственности и акты правительства по управлению хозяйственными обществами, какието обладают только 2-м документом.

Несмотря на самостоятельность в осуществлении прав акционера и участника хозяйственного общества регионами, они все же обращают внимание на то, как федеральный центр управляет своими юридическими лицами.

На федеральном уровне большинство указанных вопросов урегулировано актом Правительства РФ. Также имеется несколько иных правительственных документов по управлению отдельными акционерными обществами, представляющими особый интерес для государства (ПАО Сбербанк, ОАО «РЖД», АО «КРДВ» и др.).

В данном исследовании, для лучшего понимания происходящего, стоит отметить несколько важных моментов.

В работе под хозяйственными обществами с участием субъектов РФ будет пониматься акционерное общество и общество с ограниченной ответственностью, в котором у субъекта федерации имеется 1 акция и более.

За прошедшие 3 десятилетия с момента начала раздела единого советского государственного имущественного комплекса между публичными субъектами, в форме хозяйственных обществ в зависимости от региона дошло разное число юридических лиц. Всего, по подсчетам автора, базирующихся на открытых источниках, в собственности субъектов федерации в 2021 г. находится 1651 хозяйственное общество. Для сравнения у федерального центра на данный момент сохранилось лишь 703 ед. (в большинстве из которых у Российской Федерации доля менее 50\% - 393 ед. или 56\% от общего числа). Количество обществ продолжает снижаться.

Структура акционерной собственности в регионах также разнится. Так, в собственности столицы, Московской, Курской, Рязанской областей почти 2/3 обществ с единственным акционером - государством. В Брянской области, наоборот, подавляющее большинство обществ с долями иных акционеров.

Если описать «усредненный» субъектовый механизм управления хозяйственными обществами, то у него имеется ряд элементов.

Правительства регионов реализуют в общих чертах первично закрепленные полномочия в области управления имуществом (в частности, акциями и долями), находящихся в собственности субъектов федерации. Как правило, они лишь эпизодично занимаются данным вопросом. Чаще всего это ситуации, когда речь заходит о крупных проектах и судьбе ключевых хозяйственных обществ. Основная часть работы ложится на специализированный орган по управлению субъектовым имуществом.

Большинство региональных органов власти, занятых управлением имуществом (и государственными акционерными обществами, в частности), имеют статус министерств, а значит их руководитель входит в состав правительства субъекта федерации. Однако в силу региональной специфики устройства исполнительной власти, глава ведомства по вопросам собственности без слов «министерство» в наименовании, также может входить в правительство своего региона (например, руководитель Департамента городского имущества города Москвы).

На сегодняшний день наименования органов исполнительной власти субъектов Российской Федерации, уполномоченных по управлению имуществом, следующие:

- министерство - у 43 регионов или $51 \%$ от общего числа субъектов федерации;

- департамент- 24 или 28\%;

- агентство - 3 или 3\%;

- комитет - 10 или 12\%;

- управление - 5 или 6\%.

В силу того, что в России одной из черт управления государственным имуществом и хозяйственными обществами, в частности, является высокий уровень коррупции, в механизме управления ключевую играет контроль. Ряд полномочий в данной сфере прямо и косвенно закреплен за представительными органами.

Существующая практика нарушений и злоупотреблений со стороны управляющих государственными хозяйственными обществами, породила такие инструменты, как:

- акционерный (учредительный) контроль, производимый представителями акционера (преимущественно госслужащими, работающими в уполномоченном органе по управлению имуществом);

- ревизионная комиссия - главный и основной контрольно-ревизионный орган в каждом юридическом лице;

- комитет по аудиту - консультационный, часто образуемый формально, но имеющий при определенном подходе возможность оказывать пользу;

- подразделение внутреннего контроля (аудита) - как правило, реально не действующий орган;

- внешний аудитор - независимая ор-
143

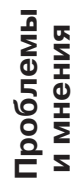


ганизация, проверяющая узкую область правильность составления бухгалтерской отчетности, наличие которой обусловлено законодательством;

- парламентский контроль - меропри ятия, осуществляемые законодательным органом и его членами;

- общественный контроль - деятельность общественных палат и общественности в весьма небольшом, в силу отсутствия доступа к информации по выявлению нарушений, масштабе;

- прокурорский надзор - осуществляют органы прокуратуры (региональные и муниципальных образований, иногда специализированные - на особо режимных объектах и др.) в рамках их полномочий;

- государственный аудит (контроль) реализуют контрольно-счетные органы, формируемые законодательными органами регионов.

Сравнивая федеральный и региональные механизмы, стоит отметить, что 1-й более сложный. В частности, относительно исполнительной власти. В подавляющем большинстве субъектов РФ отсутствуют территориальные органы органов исполнительной власти или казенные учреждения, выполняющие их полномочия (исключением, как обычно, выступает город Москва).

В России крайне затруднительно, но возможно построить эффективный механизм управления региональными хозяйственными обществами. Для этого необходимо провести большую работу по конструированию работающих норм [1; 2] и начать стоит с государственно-правовых [3].

\section{Литература}

1. Олимпиев А.Ю., Майорова Е.И. Некоторые аспекты совершенствования правового регулирования и реализации конституционного права граждан на обращения // Вестник Московского университета МВД России. - 2020. - № 1. - C. 32-34

2. Шагиева Р.В., Рычкова К.А. Акты органов местного самоуправления в системе источников российского муниципального права: проблемы теории и практики // Образование и право. - 2019. - № 5. - С. 22-29.

3. Яковлев А.Ю. Конституционные гарантии государства как акционера и практика реализации его прав // Проблемы права. 2021. № 1. - С. 48-50.

\section{References}

1. Olimpiyev A.Y., Mayorova E.I. Nekotoryye aspekty sovershenstvovaniya pravovogo regulirovaniya i realizatsii konstitutsionnogo prava grazhdan na obrashcheniya // Vestnik Moskovskogo universiteta MVD Rossii. - 2020. - № 1. - S. 32-34.

2. Shagieva R.V., Rychkova K.A. Akty organov mestnogo samoupravleniya v sisteme istochnikov rossiyskogo munitsipal'nogo prava: problemy teorii i praktiki // Obrazovaniye i pravo. - 2019. - № 5. - S. 22-29.

3. Yakovlev A.Y. Konstitutsionnyye garantii gosudarstva kak aktsionera i praktika realizatsii yego prav // Problemy prava. - 2021. - № 1. - S. 48-50.

ЯковлЕВ Александр Юрьевич, доктор политических наук, ведущий научный сотрудник Института экономики Российской академии наук. 117218, Москва, Нахимовский просп., 32. E-mail: gosypravlenie@yandex.ru.

YAKOVLEV Alexander Yurevich, Doctor of Political Science, leading researcher of Institute of Economics of the Russian Academy of Sciences. 32, Nakhimovskiy prosp., Moscow, 117218. E-mail: gosypravlenie@yandex.ru. 